\title{
Arabuluculuk Sonucunda Yapılan Milletlerarası Sulh Anlaşmaları Hakkında Birleşmiş Milletler Sözleşmesi: Singapur Konvansiyonu
}

\author{
United Nations Convention on International Settlements Agreements \\ Resulting From Mediation: Singapore Convention
}

\section{Sibel ÖZEL ${ }^{*}$}

\begin{abstract}
Öz
Uluslararası ticari meselelerde arabuluculuk bir alternatif uyuşmazlık çözüm yöntemi olarak uygulanmaktadır. Ancak tahkim kadar sıklıkla tercih edilmemektedir; zira hakem kararları bütün dünyada New York Konvansiyonu'na göre kolayca icra edilebilmekte iken arabuluculuk sonucu yapılan sulh anlaşmaları salt maddi hukuk sözleşmesi olarak nitelendirilmektedir. Bu yüzden sınır-ötesi ticari uyuşmazlıklarla ilgili arabuluculuk sonucu varılan sulh anlaşmalarının icrasını mümkün kılan bir uluslararası düzenleme yapılması gerektiği savunulmuş, böylelikle arabuluculuğun kullanımının gelişeceği ileri sürülmüştür.

Sonuç olarak Uluslararası Ticaret Hukuku ile ilgili Birleşmiş Milletler Komisyonu (UNCITRAL) Arabuluculuk Sonucunda Yapılan Milletlerarası Sulh Anlaşmaları Hakkında Singapur Konvansiyonunu hazırlamıştır. Bu makale Singapur Konvansiyonu'na göre sulh anlaşmalarının icrasını irdelemeyi amaçlamaktadır.
\end{abstract}

Anahtar Kelimeler: Arabuluculuk, sulh anlaşması, HUAK, sulh anlaşmalarının icrası, Singapur Konvansiyonu

\begin{abstract}
Mediation as an Alternative Dispute Resolution is used to solve disputes in the international commercial issues. However, it has not been preferred as much as arbitration; since arbitral awards are enforced easily around the world under the New York Convention, while settlement agreements resulting from mediation is considered as a mere contract. Hence, it has been argued that there should be an international instrument providing the enforcement of mediated settlement agreements of crossborder commercial disputes, so that the use of mediation will be promoted.

As a result, the Singapore Convention on International Settlement Agreements Resulting From Mediation was developed by the UN Commission on International Trade Law (UNCITRAL). This article is to aim to review the enforcement of settlement agreements under the Singapore Convention
\end{abstract}

Keywords: Mediation, settlement agreement, HUAK, enforcement of settlement agreements, Singapore Convention

Marmara Üniversitesi Hukuk Fakültesi Milletlerarası Özel Hukuk ABD Başkanı. 


\section{GENEL OLARAK}

Milletlerarası ticarette alternatif uyuşmazlık çözüm yöntemlerinden ( İng: ADS) biri olan arabuluculuk, uzun süre tahkimin tekelinde olan daha hızlı, daha kolay ve daha ucuz olma iddiasıyla tahkime de alternatif olarak gelişme gösterme çabası içindedir. Ancak hızlı, kolay ve ucuz bir uyuşmazlık çözüm yönteminin etkin ve yaygın kullanımı uyuşmazlığın sonlandırılmasının ötesinde, varılan sulh anlaşmasının da kolaylıkla icra edilebilmesiyle mümkündür. Zira uzlaşan taraflar yaptıkları sulhun gereğini yerine getirdiklerinde bu yöntem en etkili ADS kabul edilebilir. Ama taraflardan biri sulh anlaşmasında yükümlendiği borcu yerine getirmezse o zaman sulh anlaşmasının $^{1}$ icrası için hukuki prosedürün yerine getirilmesi gerekecektir.

Arabuluculuk sonucu yapılan sulh anlaşması niteliği gereği bir özel hukuk sözleşmesidir. Dolayısıyla bu özel hukuk sözleşmesinin icrası diğer borçlar hukuku sözleşmeleri gibidir ${ }^{2}$. Bu noktada milletlerarası tahkimin arabuluculuk karşısındaki üstünlüğü hemen ortaya çıkmaktadır. Zira milletlerarası tahkim prosedürü sonucu verilen hakem kararı tahkim yeri ülkesinin kanunları uyarınca, tahkim yeri dışındaki ülkelerde ise 1958 tarihli New York Konvansiyonu’na ${ }^{3}$ göre kolaylıkla icra edilebilmektedir ${ }^{4}$. Oysa milletlerarası arabuluculuk sonucu yapılan sulh anlaşmaları niteliği gereği özel hukuk sözleşmesinden öteye gitmediği için, tâbi olduğu arabuluculuk kanunu ${ }^{5}$ çerçevesinde icra edilme imkânı bulsa bile başka bir ülkede icrası, özel bir düzenleme olmadığı sürece mümkün olmayacak; icranın istendiği ülkede bir mahkeme kararı alınması zorunlu olacaktır. Dolayısıyla sözleşmesel bir uyuşmazlığın çözümü için arabuluculuğa başvuran taraf, harcadığı onca zaman, emek ve paranın ardından elde ettiği sulh anlaşması yerine getirilmediğinde, bu sefer sulh anlaşmasının icrası için yeniden mahkemeye veya şartları varsa tahkime müracaat etmek zorunda kalacaktır. İşte arabuluculuğun milletlerarası ticarette kabulü

1 Sulh anlaşması arabuluculuk neticesi tarafların uyuşmazlıklarının çözümü için vardıkları sonucu ortaya koyan anlaşmadır. Tarafların uyuşmazlıklarını arabuluculuk yöntemiyle çözümlemeyi kararlaştırdıkları arabuluculuk anlaşmasının icrası bu makalenin kapsamı dıșında kalmaktadır.

2 SCHNABEL, Timothy: "The Singapore Convention on Mediation: A Framework for the Cross-border Recognition and Enforcement of Mediated Settlement" 19 Pepp. Disp. Resolve. L. J. 1 (2019) s. 2-3; ZELLER, Bruno/TRAKMAN, Leon: "Mediation and Arbitration: The Process of Enforcement" 24 Unif. L. Rev. 449 (2019) s. 458. Ayrica bkz. ÇELIKKOĞLU, Cengiz Topel: “6325 Sayılı HUAK’a Göre Arabuluculuk Yoluna Başvurulması ve Çözüm Anlaşmasının Mahkeme ve İcra Usulleri ile İlişkisi” Yılmaz Ejder’e Armağan, Ankara 2014, c.1, s. 707; ERDOĞAN, Ersin/ CÖMERT, Büşra: "Arabuluculuk Sonunda Hazırlanan Anlaşma Belgesinin Hukuki Niteliği ve Anlaşma Belgesine Karşı Başvurulabilecek Hukuki Çareler” Terazi Hukuk Dergisi, c. 13, S. 138, s. 30.

3 Yabancı Hakem Kararlarının Tanınması ve İcrası Hakkında 10 Haziran 1958 tarihinde New York’ta Yapılan Sözleşme RG. 25.09.1991-21002.

4 Hakem kararları ile arabuluculuk sonucu yapılan sulh anlaşmaları arasındaki farklılıklar için bkz. STRONG, S.I: "Beyond International Commercial Arbitration - The Promise of International Commercial Arbitration" 45 Wash. U.J.L\&Pol'y 10 (2014) s. 27 vd; ZELLER, Bruno/TRAKMAN, s. 452 vd.

5 Hukuk Uyuşmazlıklarında Arabuluculuk Kanunu (HUAK) (RG. 22.06.2012-28331) m. 18(4)’e göre taraflar ve avukatları ile arabulucunun birlikte imzaladıkları anlaşma belgesi icra edilebilirlik şerhi aranmaksızın ilam niteliğinde belge sayılır. Dolayısıyla HUAK’a göre gerçekleşen milletlerarası nitelikli bir arabuluculuk faaliyeti sonucu varılan sulh anlaşması Türkiyede başka bir prosedüre gerek kalmadan icraya konabilir. Ancak başka bir ülkede gerçekleşen ya da Türkiye'de gerçekleştirilmesine rağmen HUAK hükümlerine tâbi olmayan bir arabuluculuk sonucu varılan sulh anlaşmaları Türkiye'de icraya konamaz. 
ve gelişimi bu noktada kendisini göstermektedir ${ }^{6}$. Yapılan sulh anlaşmasının sınır-ötesi icrası nasıl gerçekleşecektir? ${ }^{7}$ Bu konuda farklı çözüm önerileri ileri sürülmüştür:

a) Sulh anlaşması borç doğurucu sözleşme olduğu için diğer sözleşmeler gibi icra edilmesi dava yoluyla talep edilebilecektir. Ancak bu durumda sözleşmeye uygulanacak hukuk çerçevesinde tarafların ileri sürebileceği bütün maddi hukuk savunmaları yapılabilecek ${ }^{8}$, ayrıca for devletinin müdahaleci kuralları ve kamu düzeni anlayışı da sulh anlaşmasının icrasında değerlendirilecektir. Bu yöntem milletlerarası ticarette arabuluculuğu cazip hale getirmekten uzaktır; zira taraflar esas uyuşmazlığı çözümlemek için devlet yargısı yerine arabuluculuğa başvurmuş ancak varılan sulh anlaşmasının icrası için yine bir mahkeme kararına mecbur kalmışlardır.

b) Sulh anlaşması mahkeme kararı haline dönüştürülürse, icrası da mahkeme kararlarının icrası şeklinde olacaktır. Burada özellik arz eden husus arabuluculuk sonucu varılan sulh anlaşmasının bir mahkeme hükmü yani ilâm haline gelmesidir. Sulh anlaşması şeklen ilâm olduğunda icrası da mahkeme kararlarının icrası şeklinde olmaktadır ${ }^{9}$ Söz konusu ilâm yabancı yabancı mahkemelerde de yabancı ilâmların tanınması/tenfizi hükümlerine göre sonuç doğuracaktır.

Buna karşılık sulh anlaşması ilam haline dönüşmeyip sadece ilâm niteliğinde belge vasfını kazanırsa, icrası sadece bu niteliği taşıyan ülkede gerçekleşecektir. Hukuk Uyuşmazlıklarında Arabuluculuk Kanunu ${ }^{10}$ (HUAK) m. 18(2) ve (4)'e göre "taraflar arabuluculuk faaliyeti sonunda bir anlaşmaya varırlarsa, bu anlaşma belgesinin icra edilebilirliğine ilişkin şerh verilmesini talep edebilirler. Dava açılmadan önce arabuluculuğa başvurulmuşsa, anlaşmanın icra edilebilirliğine ilişkin şerh verilmesi, arabulucunun görev yaptığı yer sulh hukuk mahkemesinden talep edilebilir. Davanın görülmesi sırasında arabuluculuğa başvurulması durumunda anlaşmanın icra edilebilirliğine ilişkin şerh verilmesi davanın görüldüğü mahkemeden talep edilebilir. Bu şerhi içeren anlaşma ilam niteliğinde belge sayılır"11. "Taraflar ve avukatları ile arabulucunun

6 IMI tarafından gerçekleştirilen bir ankette ilgililerin \%80'i sulh anlaşmalarının küresel olarak icrasını mümkün kılan bir mekanizma olursa, sözleşmelerine arabuluculuk klozu koyacaklarını ifade etmiştir. \%84'ü böyle bir küresel icra mekanizmasının arabuluculuğun kullanımını artıracağını söylemiştir. Bkz. REED, Lucy: "Ultima Thule: Propects for International Commercial Mediation" (NUS Centre for International Law Working Paper 19/03-January 2019) (http://cil.nus.edu.sg/library/)s. 19.

7 Sulh anlaşmaları çoğu kez rızaen yerine getirilse de aksi durumlar da olmaktadır. Çeşitli faktörler bir tarafın sulh anlaşmasının gereklerini yerine getirmesine engel olabilmektedir. Örneğin arabuluculuk prosedürünün tamamlanmasından sonra niyetlerdeki değişim, şirket sahibi ya da yöneticisinin değişmesi, kambiyo oranlarındaki ani değişim gibi dış faktörler, hükümetin aldığı bir karar neticesi sulh anlaşmasının icrasının imkânsız hale gelmesi vb nedenlerle anlaşma taraflardan biri tarafından icra edilmeyebilir. Bkz. ABOU EL FARAQ, Muhammed Salem: "The Enforcement of Settlement Agreements Resulting From Mediation - A Qatari Perspective" 19 Asian Bus. Law. 49 (2017) s. 53.

8 SUSSMAN, Edna: “The Singapore Convention the Enforcement and Recognition of International Mediated Settlement Agreements" 3 ICC Dispute Resolution Bulletin, 42 (2018) s. 46.

9 Bkz. Id. s. 46. Katar Tahkim ve Arabuluculuk Kanunu tasarısı için bkz. ABOU EL FARAQ, s. 59 vd.

10 Bkz. dn. 5.

11 Sulh anlaşmasına mahkeme tarafından icra edilebilirlik şerhi verilmesi sulh anlaşmasını ilam haline getirmemekte; ilam niteliğinde belge olarak kabulünü sağlamaktadır. Bu itibarla HMK m. 313’e göre yapılan sulh anlaşmasından 
birlikte imzaladıkları anlaşma belgesi icra edilebilirlik şerhi aranmaksızın ilam niteliğinde belge sayılır”. Dolayısıyla HUAK’a göre gerçekleşen bir arabuluculuk sonucu varılan sulh anlaşması ile Türkiye'de icra takibi yapılabilir; ancak bu anlaşma ilâm olmadığı için yabancı bir mahkemede özel bir düzenleme olmadıkça yabancı mahkeme kararı olarak tenfiz edilemez. Aynı şekilde yabancı bir ülkede o ülkenin arabuluculuk kanununa göre yapılmış bir arabuluculuk faaliyeti sonucu gerçekleşen sulh anlaşması o ülkede ilâm niteliğinde belge olsa bile ilâm olmadığı için Türkiye'de MÖHUK ${ }^{12} \mathrm{~m}$. 50 vd hükümlerine göre tenfiz edilmeyecektir ${ }^{13}$.

c) Sulh anlaşmasının bir hakem kararı haline getirilmesi durumunda söz konusu hakem kararının icrası ülkelerin kendi milletlerarası tahkim kanunları, 1958 New York Konvansiyonu veya yabancı hakem kararlarının tanınması ve tenfizi hükümlerine göre gerçekleşebilecektir. Türk Milletlerarası Tahkim Kanunu (TMK) ${ }^{14}$ m. 12/D’ye göre tahkim yargılaması sırasında taraflar sulh olursa, tahkim yargılamasına son verilir. Tarafların istemini uygun bulan hakem veya hakem kurulunca sulh, hakem kararı olarak tespit edilir ${ }^{15}$. Dolayısıyla hakem kararı olarak tespit edilen sulh anlaşmaları artık hakem kararı olarak icra edilebilir hale gelmektedir. $\mathrm{Bu}$ durum uyuşmazlı̆̆ın önce arabuluculuk sonra tahkim ile çözümlenmesi konusunda yapılan anlaşmalar için işlerlik kazanacaktır ${ }^{16}$. Ancak tahkim anlaşmasının olmadığı, uyuşmazlığın sadece arabuluculukla çözümlenmesinin kararlaştırıldı̆̆ı (arabuluculuk anlaşması) durumlarda, prosedür sonucu yapılan sulh anlaşmasının hakem kararı haline getirilmesi mümkün olabilir mi? Burada uyuşmazlık çözümlendikten sonra hakem ataması yapılacak ve o hakemden mevcut sulh anlaşmasını hakem kararı haline getirmesi istenecektir. Bu noktada önem arz eden husus ulusal tahkim kanunları ve özellikle New York Konvansiyonu'na göre böyle bir hakem kararının icrasının mümkün olup olmadığıdır ${ }^{17}$.

Milletlerarası Ticari Tahkimle ilgili Model Kanun ${ }^{18}$ m. 30(2) tarafların anlaşmasıyla varılan sulh anlaşmasının bir hakem kararı formunda da düzenlenmesini kabul etmiş ve bu tür bir kararın diğer kararlarla aynı statüde olduğuna vurgu yapmıştır. Ancak bu şekilde verilen kararların

farklı bir durum ortaya çıkmaktadır. Zira HMK m. 315’e göre sulh kesin hüküm gibi sonuç doğurur. Oysa ilam niteliğindeki belgeler kesin hüküm etkisi doğurmazlar. İlam niteliğindeki belgelere karşı kanun yollarına müracaat edilemez; şartları varsa irade bozukluğu sebebiyle iptali istenebilir. KOÇYİĞİT, İlker/PULUR, Alper: Ticari Uyuşmazlıklarda Dava Şartı Arabuluculuk, Hukuk İşleri Genel Müdürlüğü Arabuluculuk Daire Başkanlığı Yayını, Mart 2019, s. 42-43. (http://www.adb.adalet.gov.tr ) (10.10.2019); ÇELIKKOĞLU, s. 708 vd; ERDOĞAN/CÖMERT, s. 37 vd; TAŞPOLAT-TUĞSAVUL, Melis: "Arabuluculuk Faaliyeti Sonunda Varılan Anlaşmanın Hukuki Niteliği" Galatasaray Üniversitesi Hukuk Fakültesi Dergisi, 2019/1, s. 356 vd, 360 vd.

125718 sayılı Milletlerarası Özel Hukuk ve Usul Hukuku Hakkında Kanun (RG. 12.12.2007-26728).

13 MÖHUK’a bu hususa ilişkin ekleme yapılmasına ilişkin görüş için bkz. PÜRSELIM, Hatice Selin: "Yabancıllk İçeren Arabuluculuk Usulü ve Bağlayıcılık Hakkında Düşünceler" Marmara Üniversitesi Hukuk Fakültesi Hukuk Araştırmaları Dergisi, c. 20, S.2, 2014, s. 16.

14 RG. 5.07.2001-24453.

15 Ayrıntılı bilgi için bkz. ELÇİN, Doğa: Milletlerarası Ticari Tahkim Hukukunda Sulh, Ankara 2019, s. 91 vd.

16 Tahkim-arabuluculuk-tahkim (arb-med-arb) gibi uyuşmazlık çözüm yönteminin kararlaştırıldığı durumda tarafların yaptığı sulh anlaşması kolaylıkla hakem kararı olarak tenfiz kabiliyetine sahip olmaktadır. Bkz. BOULLE, Laurence/QIN, Jay: "Globalising Mediated Settlement Agreements" 3 J.Int'l\&Com.L. 33 (2016) s. 40 vd.

17 Farklı görüşler için bkz. SUSSMAN, s. 47; ELÇíN, s. 211 vd.

18 UNCITRAL Model Law on International Commercial Arbitration www.uncitral.org 
New York Konvansiyonu çerçevesinde tenfiz edilmesi söz konusu olduğunda, Konvansiyonun uyuşmazlık çözümlendikten sonra atanan bir hakem tarafından verilen kararları da kapsayıp kapsamadığının irdelenmesi gerekmektedir. New York Konvansiyonu mevcut veya ilerde doğabilecek ihtilaflar için tahkime gitmeyi öngörürken, uyuşmazlığın hakem ataması aşamasında mevcut olması gerektiğine dair açık bir hüküm getirmemiştir. Bu nedenle uyuşmazlık sulh anlaşmasıyla çözümlendikten sonra hakem ataması yapılması ve o hakemin sulh anlaşmasını hakem kararı olarak vermesi halinde bu kararın New York Konvansiyonu çerçevesinde tenfiz edileceği savunulmaktadır ${ }^{19}$. Ancak uyuşmazlık çözümlendikten sonra tahkime gitme imkânının olmadığı, hakemin atandığı anda mevcut bir uyuşmazlığın bulunması gerektiği savları New York Konvansiyonu’na göre tenfiz imkânını sorunlu hale getirebilecek; ülkeden ülkeye farklı yorumların yapılmasını mümkün kılabilecektir. Bu nedenle ABD sulh anlaşmalarının sınırötesini icrasını gerçekleştirecek bir düzenleme yapılması önerisinde bulunmuştur ${ }^{20}$.

Bu bağlamda UNCITRAL Çalışma Grubu konuya ilişkin uluslararası bir sözleşme yapmaya odaklanmıştır ${ }^{21}$. 2014'de başlayan çalışma UNCITRAL'in 25 Haziran 2018'de yapılan 51. Toplantısında Arabuluculuk Sonucunda Yapılan Milletlerarası Sulh Anlaşmaları Hakkında Sözleşme metnini onaylaması ile sonuçlanmıştır ${ }^{22}$. Bu çalışma sürecinde Avrupa Birliği konuya ilişkin milletlerarası sözleşme yapılmasını gerekli görmediğini, sulh anlaşmalarının icrasını iç hukuka bırakan Model Kanunun ötesinde uyumlaştırma çabalarının gerçekçi olmadığını açıklamıştır23. Ancak Çalışma Grubu Model Kanun ile Konvansiyon çalışmalarını birlikte yürütmüştür ${ }^{24}$.

Konvansiyonun hazırlık aşamalarında tartışılan hususlardan biri de sadece parasal sulh anlaşmalarının icrası için düzenleme yapılması düşüncesidir. AB tarafindan talep edilen bu sınırlama Çalışma Grubu tarafından reddedilmiştir. Sulh anlaşmaları parasal ya da parasal olmayan unsurları bünyesinde barındırabilir ve her iki borcun icrası da Konvansiyon kapsamında garanti altına alınmıştır ${ }^{25}$.

19 SUSSMAN, s. 47; ABOU EL FARAQ, s. 65. Hakemlerin sulh anlaşması yapılmadan önce atanmaları halinde, sulh anlaşmalarının rızaen verilen hakem kararlarına dönüştürülmesi ve bu hakem kararlarının tenfizi genel olarak kabul edilmektedir. Bkz. SUSSMAN, s. 47-48.

20 SUSSMAN, s. 46,48.

21 Ayrıntılı bilgi için bkz. SCHNABEL, s. 4 vd.

22 SUSSMAN, s. 43. Metin Birleşmiş Milletler Genel Kurulu’nda 20 Aralık 2018 tarihinde kabul edilmiştir. SILVESTRI, Elisabetta: "The Singapore Convention on Mediated Settlement Agreements: A New String to the Bow of International Mediation" Revista Electronica de Direito Processual, Rio de Janeiora Ano 13, v. 20, No. 2 Maio a Agosto de 2019, s. 190. Konvansiyonla ilgili bkz. REED, s. 11 vd; ZELLER/TRAKMAN, s. 453 vd; ÖZSUNAY, Ergun: "Arabuluculuk Sonucunda Yapılan Uluslararası Sulh Anlaşmaları Hakkında Birleşmiş Milletler Sözleşmesi: Singapur Arabuluculuk Sözleşmesi Türk Hukukuyla Uyumu Bakımından Bir Değerlendirme” İstanbul Barosu Dergisi, Mayıs-Haziran 2019, c. 93, S. 3, s. 31 vd; YARAR, Güven: Milletlerarası Özel Hukukta Arabuluculuk, İstanbul 2019, s. 153 vd.

23 Bazı delegeler arabuluculuğun gelişmesi için bağlayıcı olmayan Model Kanun gibi çalışmaların daha etkili olacağını savunmuştur. Bkz. SCHNABEL, s. 7. Bazı delegeler de bağlayıcı bir düzenlemenin arabuluculuğun henüz gelişme göstermediği ülkeler için vakitsiz olduğunu ileri sürmüştür. Id. s. 7.

25 Bkz. Id. s. 12-13. 
Singapur Konvansiyonu çifte exequatur’a izin vermeyecek bir düzenleme getirmiştir. Bir başka ifadeyle sulh anlaşmaları ulusal mahkeme veya noter onayı olmadan doğrudan icraya konu olabilecektir ${ }^{26}$.

Singapur Konvansiyonu yabancı hakem kararlarının tanınması ve tenfizini düzenleyen 1958 New York Konvansiyonu ile aynı amaca hizmet etse de iki noktada farklılı̆̆ın vurgulanması gerekmektedir:

(i) New York Konvansiyonu yabancı hakem kararlarını esas aldığı için tahkim yeri hakem kararına yabancılık kıstası vermesi açısından önemlidir. Oysa arabuluculukta arabuluculuk yeri yoktur; arabuluculuğun yabancı bir ülkede gerçekleşmesi gerekmez.

(ii) New York Konvansiyonu tahkim anlaşmasının geçerlilik şartlarını da düzenlemiştir; Singapur Konvansiyonu ise arabuluculuk anlaşmasının geçerliliği ile ilgili bir hüküm getirmemiş sadece arabuluculuk sonucu varılan sulh anlaşmaları ile ilgili düzenleme yapmıştır. Dolayısıyla taraflar arabuluculuk anlaşması yapmadan sulh anlaşması yapmışlarsa, bu sulh anlaşmasının icrası da Singapur Konvansiyonu kapsamındadır 27 .

7 Ağustos 2019'da imzaya açılan Singapur Konvansiyonu, 2002 tarihli Model Kanunun da revize edilmesini sağlamış ${ }^{28}$ böylelikle hem Model Kanun hem de Singapur Konvansiyonu sulh anlaşmalarının sınır-ötesi icrasında paralel hükümler getirmiştir.

Singapur Konvansiyonu ile arabuluculuk sonucu yapılan sulh anlaşmalarının sınır-ötesi icrası mümkün olacak, bu sayede bir maddi hukuk sözleşmesi yeni bir statü kazanarak kolayca icra edilebilir hale gelecektir ${ }^{29}$. Sulh anlaşmalarının icrasının kolaylaştırılması aynı zamanda ticari arabuluculuğun gelişmesine de katkıda bulunacaktır ${ }^{30}$.

\section{SINGAPUR KONVANSIYONU'NUN KAPSAMI}

Singapur Konvansiyonu'na göre sulh anlaşmalarının icra edilebilmesi için arabuluculuk sonucu yapılmış olması, milletlerarası nitelik taşıması, ticari olması ve açıkça dışlanan konulara ilişkin olmaması gerekmektedir (m. 1).

\section{A. Arabuluculuk}

İcrası istenen sulh anlaşması arabuluculuk sonucu yapılan bir sulh anlaşması olmalıdır. Bu noktada arabuluculuk tanımı m. 2(3)'de yapılmıştır: Arabuluculuk, tarafların uyuşmazlıklarını

26 Id. s. 13-14. Bu bağlamda New York Konvansiyonu esas alınmıștır. Özellikle elektronik ortamda yapılan sulh anlaşmalarında arabuluculuk prosedürünün yerini tanımlamak da mümkün olmayacaktır. Id. s. 11.

27 Id. s. 14.

28 UNCITRAL Model Law on International Commercial Mediation and International Settlement Agreements Resulting From Mediation, 2018 (amending the UNCITRAL Model Law on International Commercial Conciliation 2002) http://www.uncitral.org/pdf/english/commissionsession/51st-session/Annex_II.pdf (9.10.2019)

SILVESTRI, s. 191.

30 SILVESTRI, s. 191; CHUA, Eunice: "The Singapore Convention on Mediation - A Brighter Future for Asian Dispute Resolution” Asian Journal of International Law, 1 (2018) s. 2; REED, s. 18. 
onlara çözüm dayatma yetkisi olmayan 3. bir kişi ya da kişilerin (arabulucu) yardımıyla dostane çözüme ulaşmak için çaba gösterdikleri bir süreç anlamına gelir. Bu sürecin gerçekleşmesinde temel alınan ya da kullanılan terimin bir önemi yoktur. Konvansiyon sürecin hangi isimle gerçekleşmiş olduğunun önemli olmadığına ve sürecin tanımlayıcı unsurlarının dikkate alınması gerektiğine özel bir vurgu yapmıştır ${ }^{31}$. Dolayısıyla arabuluculuk, uzlaştırma veya başka bir isimle adlandırılan süreç $c^{32}$ Konvansiyon kapsamında arabuluculuk anlamına gelmektedir.

Konvansiyon kapsamında arabuluculuğun bir mahkeme/hakem heyetinin talimatı veya tavsiyesi ile olması ya da ihtiyari veya zorunlu olması arasında fark yoktur. Önemli olan nokta tarafların kendi istekleriyle sulh anlaşması yapmasıdır. Bu bağlamda arabuluculuğun bir kurum aracılığıyla gerçekleştirilmesi de zorunlu değildir ${ }^{33}$.

Konvansiyonun çerçeve bir tanımla belirlediği arabuluculukta kilit nokta tarafların üçüncü bir kişinin yardımıyla uyuşmazlıklarını çözümlemeleridir. Üçüncü kişinin çözüm önerisini taraflara uygulatma yetkisi varsa bu durum arabuluculuk tanımı ile örtüşmemektedir ${ }^{34}$. Üçüncü kişinin çözüm önerisi getirme yetkisinin olması Konvansiyonun uygulama alanını bertaraf etmemektedir. Zira burada da tarafların bu öneriyi kabul zorunluluğu yoktur.

\section{B. Milletlerarasılık}

Singapur Konvansiyonu uygulama alanını milletlerarası sulh anlaşmaları ile sınırlamıştır. Burada kullanılan milletlerarası terimi yabancılık unsurunu içermektedir. Sulh anlaşmalarının hangi durumda milletlerarası nitelik kazandığı m. 1(1)'de açıklanmıştır. Buna göre

(a) Sulh anlaşmasının taraflarından en az ikisinin işyerleri birbirinden farklı ise; veya

(b) Sulh anlaşmasının taraflarının işyerlerinin bulunduğu ülke

(i) Sulh anlaşmasına göre borçların esaslı bir bölümünün ifa edileceği ülkeden farklı ise; veya

(ii) Sulh anlaşmasının konusunun en yakın ilişkide olduğu ülkeden farklı ise

31 UNCITRAL Model Kanun 2002 versiyonunda conciliation “uzlaştırıcılık” terimi kullanılmış buna karşılık 2018 versiyonunda mediation "arabuluculuk" terimi tercih edilmiștir. Ancak her iki terimin birbirinin yerine kullanılabileceği; terminoloji değişikliğinin kavramın esası hakkında bir değişikliğe yol açmadığı not edilmiştir. Bkz. Model Kanun (dn. 28) dn. 2. UNCITRAL'in mediation terimini tercih etmesi bu terimin daha yaygın olarak kullanılmasından kaynaklanmaktadır. Conciliation (uzlaştırıcılık) tarafsız bir uzlaştırıcının taraflara çözüm önerisinde bulunduğu durumlar için kullanılırken, mediation bütün süreçleri kapsar şekilde kullanılmaktadır. SUSSMAN, s. 49-50. 2012 tarihli Türk HUAK m. 2(b)'de tarafların çözüm üretmesine yardımcı olan bağımsız ve tarafsız üçüncü kişilerin katılımıyla yürütülen bir uyuşmazlık çözüm yöntemi olarak tanımlanan arabuluculuk, 2017 değişikliği ile arabulucuların taraflara çözüm önerisi de getirebileceği bir yöntem olarak tariflendirilmiştir.

32 AB kendi Yönergesindeki tanımı esas alarak Konvansiyonun "yapılandırılmış süreç" (structured process) sonucu gerçekleşen sulh anlaşmalarını esas almasını talep etmiştir. Bu durumda resmi olmayan arabuluculuk süreçleri kapsam dışında kalacak ancak Model Kanunu benimseyen ulusal bir kanun çerçevesinde yapılan arabuluculuk faaliyetleri Konvansiyona dahil olacaktır. Çalışma Grubu yapılandırılmış sürecin ne olduğuna dair tatminkâr bir yanıt alamadığı gerekçesiyle talebi reddetmiştir. Bkz. SCHNABEL, s. 12-13.

SCHNABEL, s. 17; SILVESTRI, s. 193. 
Anlaşma Konvansiyon kapsamında milletlerarası niteliktedir ${ }^{35}$.

Milletlerarası nitelik sulh anlaşmasının kurulması anında mevcut olmalıdır. Arabuluculukta her iki tarafın işyeri aynı ülkede olsa da yapılan sulh anlaşmasında borcun ifa yeri farklı bir ülkeyi işaret ediyorsa ya da sulh anlaşmasının konusunun en sıkı bağlantıda olduğu ülke bir başka ülke ise sulh anlaşması milletlerarası nitelik kazanmıştır ${ }^{36}$.

Birden fazla işyeri olan taraf açısından işyeri, arabuluculuk sözleşmesiyle en yakın bağlantısı olan işyeri anlamına gelmektedir (m. 2(1)(a)). İşyeri olmayan taraf açısından ise işyeri kavramı onun mutat meskenini ifade etmektedir (m. 2(1)(b)).

Singapur Konvansiyonu yabancı hakem kararlarının tenfizine ilişkin New York Konvansiyonu’nu örnek almasına rağmen yukarıda açıkladığımız üzere tahkimde geçerli olan bazı kavramlardan uzak durmuştur. Hakem kararının yabancılığının tespitinde önem arzeden tahkim yeri kavramı arabulucukta yoktur. Bu itibarla Singapur Konvansiyonu'nda “arabuluculuk yeri” terimi yer almamaktadır. Özellikle elektronik ortamda yapılan arabulucukta bu yerin tespiti mümkün değildir, sulh anlaşmasının yapıldı̆̆ıyer deönemli değildir. Bu nedenle Singapur Konvansiyonu'nda milletlerarası nitelik bu unsurlar dikkate alınarak belirlenmemiştir. Bunun doğal sonucu arabuluculuk prosedürünün veya sulh anlaşmasının belirli bir ülke mevzuatına uygun olmaması (örneğin sadece sicile kayıtlı arabulucuların faaliyet göstermesi vb) sulh anlaşmasının icrasında önem arz etmeyecektir ${ }^{37}$. Dolayısıyla HUAK hükümlerine göre gerçekleşmeyen ve Türkiye’de arabuluculuk lisansı olmayan bir Türk vatandaşının Türkiyede gerçekleştirdiği arabuluculuk faaliyeti sonucu yapılan sulh anlaşması diğer şartları taşımak koşuluyla Türkiye’de Konvansiyon kapsamında icra edilebilecektir.

\section{Ticari olma}

Milletlerarası sulh anlaşmasının ticari uyuşmazlıkları çözümleyen bir anlaşma olması gerekmektedir (m. 1(1)). Ticari tanımı Konvansiyonda yapılmamıştır ${ }^{38}$. Bu itibarla ticari teriminin geniş yorumlanması savunulmaktadır. İnşaat ve doğal kaynakların çıkarılmasında devlet-yatırımcı uyuşmazlıkları da ticari uyuşmazlık kavramına girmektedir ${ }^{39}$. Ancak sulh anlaşmasının icrasının talep edildiği ülkede ticari olarak vasıflandırılan bir uyuşmazlık aşağıda belirtildiği üzere Konvansiyonun kapsamı dışında tutulmuşsa, o tür uyuşmazlıkların çözümü için yapılan sulh anlaşmaları Konvansiyon kapsamında icra edilmeyecektir.

Aynı tanım Model Kanun m. 2'de de yer almaktadır.

SCHNABEL, s. 20.

Bkz. SCHNABEL, s. 22; SILVESTRI, s. 193.

Model Kanun dn.1'de ticari kavramı tahdidi olmamak üzere açıklanmıştır. Buna göre mal veya hizmet tedariki veya değişimi için yapılan muameleler; distribütörlük sözleşmeleri; ticari temsil veya acentelik; factoring; leasing; inşaat işleri; danışmanlık; mühendislik; lisans; yatırım; finans; bankacılık; sigorta; imtiyaz sözleşmeleri; joint venture ve diğer sanayi ve ticaret işbirliği; hava, deniz, raylı sistem veya kara yoluyla eşya veya yolcu taşıma işleri ticaridir.

SCHNABEL, s. 22-23. 


\section{Kapsam dışı haller}

1. Yukarda belirtildiği üzere Konvansiyon sadece ticari uyuşmazlıkları çözümleyen sulh anlaşmaları için uygulanacaktır. Bu konudaki vasıflandırma Konvansiyonda açık bir tanım olmadığı için sulh anlaşmasının icrasının talep edildiği ülke hukukuna göre (lex fori) yapılacaktır. Ancak Konvansiyon açıkça taraflardan birinin (tüketicinin) kişisel, ailevi veya evle ilgili maksatlarla yapmış olduğu işlemlerden kaynaklanan uyuşmazlıkları çözümleyen sulh anlaşmalarını kapsam dışı bırakmıştır (m. 1(2)(a)). Dolayısıyla kişisel, ailevi veya evle ilgili işlemlerden kaynaklanan uyuşmazlıklar hiçbir biçimde ticari uyuşmazlık olarak sınıflandırılmayacak ve bu noktada varılan sulh anlaşmalarının icrası Konvansiyon kapsaminda istenemeyecektir.

2. Konvansiyon aile, miras ve iş hukukundan kaynaklanan uyuşmazlıkların çözümlendiği sulh anlaşmalarını da kapsam dışı bırakmıştır m. 1(b)(2)(b)).

3. Konvansiyon

a. Bir mahkeme tarafindan onaylanan veya mahkeme prosedürü sonucu yapılan sulh anlaşmaları ile

b. Taraf ülkede mahkeme kararı olarak icra edilebilen sulh anlaşmalarına uygulanmayacaktır (m. 1(3)(a)(i)(ii)).

Bir mahkeme kararı haline gelmiş sulh anlaşmalarıyla mahkeme kararı olarak icra edilebilen sulh anlaşmalarının kapsam dışında bırakılması söz konusu sulh anlaşmalarının Lahey Konvansiyonları çerçevesinde değerlendirilebilmelerinden kaynaklanmaktadır ${ }^{40}$. Zira mahkeme kararı olarak icra edilebilen sulh anlaşmaları yabancı ülkelerde de yabancı mahkeme kararlarının tanınması/tenfizi hükümlerine göre hukuki sonuç doğurmaktadır. Bu itibarla sulh anlaşmasının Singapur Konvansiyonu kapsamının dışında kalması için o ülkede mahkeme kararı olarak icra edilebilir olması yeterlidir. Singapur Konvansiyonu milletlerarası sulh anlaşmalarının mahkeme kararları gibi icra edilemeyeceği ülkelerde de icra edilmesini mümkün kılmak amacıyla yapılmış bir düzenlemedir.

HUAK hükümlerine göre yürütülen bir arabuluculuk faaliyeti neticesinde varılan sulh anlaşması, milletlerarası ticari sulh anlaşması olsa bile HUAK m. 18'e göre ilam niteliğinde belge olduğu ve buna göre Türkiye'de icra edilebildiği için Konvansiyon kapsamında değildir. Ancak Türkiye'de ilâm niteliğinde belge olarak icra edilebilen sulh anlaşması yabancı ülkede bu nitelikte olmadığı için, Singapur Konvansiyonu kapsamına girecektir. Diğer yandan Türkiyede HUAK hükümlerine göre gerçekleşmeyen bir arabuluculuk sonucu yapılan sulh anlaşmasının Türkiye’de icrası da Konvansiyon hükümlerine tâbi olabilecektir. Aynı şekilde başka bir ülkede ulusal bir arabuluculuk kanununa göre veya bir kuruma bağlı olarak yürütülen arabuluculuk sonuncunda yapılan sulh anlaşması da yabancı ülkede ilâm niteliğinde belge olarak kabul edilse

40 Bkz. Convention of 30 June 2005 on Choice of Court Agreements www.hcch.net; Convention of 2 July 2019 on the Recognition and Enforcement of Foreign Judgments in Civil or Commercial Matters www.hcch.net. Ayrintıli bilgi ve eleștiri için bkz. SCHNABEL, s. 25. 
bile, Türkiye’de ilam niteliğinde belge olarak icra edilemeyeceği için Singapur Konvansiyonu çerçevesinde icra edilebilir.

4. Konvansiyon bir hakem kararı olarak kaydedilen veya icra edilebilen hakem kararları için de uygulanmayacaktır (m. 1(3)(b)). Hakem kararlarının icrası New York Konvansiyonu’na göre gerçekleşeceği için Singapur Konvansiyonu kapsamı dışında tutulmuştur.

\section{E. Genel Prensipler}

Singapur Konvansiyonu taraf devletlere konvansiyonda belirtilen şartlara ve usul kurallarına uygun sulh anlaşmalarını icra etme yükümlülüğü getirmektedir (m. 3(1)). Bu yükümlülük sulh anlaşmasının tanınması ve tenfizini içermektedir. Ancak Konvansiyon açıkça "tanıma" kavramını kullanmaktan çekinmiştir. Zira bu kavram kesin hüküm "res judicata” etkisi içerdiği ve sulh anlaşmaları kesin hüküm etkisine sahip olmadığı için AB sulh anlaşmalarına önleyici etki sağlanmaması yönünde görüş bildirmiştir. Ancak bazı durumlarda icra değil, sadece tanıma ihtiyaca cevap vereceği ve tanıma kavramı farklı hukuklarda farklı nitelendirildiği için Konvansiyon tanıma terimini kullanmadan, tanımanın içeriğine sonuç bağlamıştır (m. 3(2) $)^{41}$. Buna göre bir tarafın sulh anlaşmasıyla zaten çözümlendiğini iddia ettiği bir meseleden dolayı bir uyuşmazlık çıktığında, Konvansiyona taraf ülke, o meselenin zaten çözümlenmiş olduğunu ispat edebilmesi için ilgili tarafa bu Konvansiyondaki şartlara ve usullere göre sulh anlaşmasına başvuru imkânı getirmek zorundadır. Dolayısıyla sulh anlaşması uyuşmazlığın çözümlendiğine ilişkin def'i olacaktır. Böyle bir durumda sulh anlaşmasının Konvansiyon şartlarını taşıdığının tespiti anlaşmanın içeriğinin tanınması anlamına gelmektedir.

\section{SULH ANLAŞMASININ ICRASINA ILIŞKIN USULI ŞARTLAR}

Konvansiyon sulh anlaşmasının icrası için bazı formalitelerin yerine getirilmesini aramıştır. Madde 4'de aranan şartlar tahdididir ve taraf devletler bunları aşan şartlar talep edemezler ${ }^{42}$.

a) Sulh anlaşması yazılı olmalıdır(m. 1(1)). Yazılılık şartı anlaşmanın içeriğinin ispatı açısından önemli olduğu gibi tarafların anlaşmayı yaparken içeriğe daha dikkatle odaklanmalarını da sağlayacaktır ${ }^{43}$. Konvansiyon yazılılığın ne anlama geldiğini m. 2(2)'de tanımlamıştır. Buna göre içeriği herhangi bir şekilde kayıt altına alınmış olan sulh anlaşması yazılı olarak mütalaa edilecektir. Eğer anlaşmadaki bilgi sonraki bir referans için erişilebilir ise elektronik iletişim ile yapılan anlaşmalar da yazılılık şartını gerçekleştirmiş olur. Dolayısıyla sulh anlaşmasının e-posta aracılığıyla yapılması Konvansiyon kapsamı için uygundur ${ }^{44}$.

41 Bkz. SCHNABEL, s. 35-36; CHUA, s. 4.

42 SCHNABEL, s. 32.

43 Id. s. 28 .

44 Sulh anlaşmasının tek bir belgede yer alması zorunlu değildir. Karşılıklı e-posta gönderimi ile de sulh anlaşması yapılabilir. Konu ile ilgili tartışmalar için bkz. SCHNABEL, s. 29. 
b) Sulh anlaşması taraflarca imzalanmalıdır (m. 4(1)(a)). Tarafların temsilcileri tarafından imza atılması halinde de şart yerine gelmiş sayılacaktır ${ }^{45}$. Konvansiyon elektronik iletilerde imza koşulunun yerine getirilmesinde kullanılan yöntemin uygun olduğu kadar güvenli olmasını da şart koşmuştur (m. 4(2)(a)(b)(i)(ii)).

c) Sulh anlaşmasının arabuluculuk sonucu yapıldığının ispatlanması gerekmektedir (m. 4(1) (b)). Bunun için

(i) Arabulucunun da imzasının bulunduğu sulh anlaşmasının yetkili makama sunulması gerekir (m. 4(1)(b)(i)). Ancak bazı ülkelerde arabulucunun sulh anlaşmasını imzalamasına izin verilmediği için her sulh anlaşmasında zorunlu olarak arabulucunun imzasının olmayacağı da göz önüne alınmıştır ${ }^{46}$.

(ii) Arabuluculuğun gerçekleştiğini gösteren ve arabulucu tarafından imzalanan bir belge de aynı işlevi görebilir (m. 4(1)(b)(ii)). Sulh anlaşmasından ayrı olarak düzenlenen bu belge sadece arabuluculuk prosedürünün gerçekleştiğini onaylamaktadır ${ }^{47}$.

(iii) Arabuluculuğu gerçekleştiren kurumdan alınan onay belgesi ispat için yeterlidir ( $\mathrm{m}$. 4(1)(b)(iii). Kurumsal arabuluculuk sonucu yapılan sulh anlaşmalarının icrası talebinde kurumun arabuluculuğu ispatlayan belgesi Konvansiyon kapsamında uygundur.

(iv) Yukarıdaki üç çeşit belgenin temin edilememesi halinde yetkili makamın kabul edebileceği her türlü delille arabuluculuk ispatlanabilir (m. 4(1)(b)(iv)). Alternatif delillere örnek olarak arabuluculuk anlaşması ve buna ek olarak arabulucuya ödeme yapıldığını gösteren belge zikredilebilir ${ }^{48}$.

\section{SULH ANLAŞMASININ ICRASININ REDDi SEBEPLERi}

Singapur Konvansiyonu tahdidi olarak sulh anlaşmasının icrası talebinin reddi sebeplerini sıralamıştır (m. 5). Bu sebeplerin varlığı halinde sulh anlaşmasının icrasının reddi zorunlu değildir; yetkili makam talebi reddebileceği gibi icra kararı da verebilir. Diğer yandan taraf devletler Singapur Konvansiyonu’nu iç hukuklarına dahil ederken bu sebeplerin tümünü kanunlaştırmak zorunda değildir. Bir başka ifadeyle red sebeplerinden bazılarını iç hukuk hükümlerine dahil etmeyebilirler ${ }^{49}$.

\section{a) Ehliyetsizlik}

Sulh anlaşmasının bir tarafı bu anlaşmayı yaparken ehliyetsiz ise anlaşmanın icrası reddedilebilecektir (m. 5(1)(a)). Taraflardan birinin reşit olmaması veya ayırt etme gücünü

45 SCHNABEL, s. 29.

46 Id. s. 31.

47 Id. s. 31

48 Id. s. 32.

49 SCHNABEL, s. 42; SILVESTRI, s. 195. 
kaybetmesi durumunda bu şart gündeme gelebilir. Ancak ticari arabuluculukta çoğu kez avukatlar da prosedürde yer aldığı için bu hükmün uygulanma imkânı az olacaktır ${ }^{50}$.

\section{b) Sulh anlaşmasının geçersizliği}

Sulh anlaşması hükümsüz, tesirsiz veya uygulanması imkânsız ise icra talebi reddedilebilecektir (m. 5(1)(b)(i)). Bu hüküm New York Konvansiyonu m. II(3)'de yer alan tahkim anlaşmalarının geçersizlik şartlarıyla aynıdır.

Sulh anlaşmasının geçersizliği tarafların seçtiği hukuka, böyle bir hukuk seçimi yoksa icra için başvurulan taraf devletin yetkili makamının uygulayacağı varsayılan hukuka tâbidir (m. 5(1)(b)(i)). Dolayısıyla bir özel hukuk sözleşmesi olan sulh anlaşması için irade muhtariyetine önem verilmiş ve tarafların sulh anlaşmasının tâbi olacağı hukuku serbestçe belirlemelerine imkân tanınmıştır. Ancak bu seçimin sulh anlaşmasının icrasının talep edildiği ülke hukukuna göre geçerli olması gerekmektedir. Bu yönde bir hukuk seçimi olmadığında anlaşmanın geçersizliği iddiası ilgili makamın kanunlar ihtilafı kurallarına göre belirlenecektir ${ }^{51}$. Milletlerarası sulh anlaşmasının Türkiye'de icrası talep edildiğinde anlaşmanın geçersizliğine ilişkin iddialar tarafların hukuk seçmediği durumda MÖHUK m. 24(4)'e göre belirlenecektir. Uygulanacak hukuk anlaşmanın en sıkı ilişkide bulunduğu hukuktur. Sulh anlaşmasında karakteristik edim teorisine dayanan karinenin uygulanma imkânı olmadığını vurgulamak gerekir. Zira sulh anlaşmasında sözleşmeyi karakterize eden, ona damgasını vuran bir edim yoktur ${ }^{52}$. Burada taraflar uyuşmazlıklarını çözümlemiş ve bu itibarla tarafların hepsi veya biri edim yükümlülügü altına girmiştir. Edimin ifa yeri çoğu zaman sulh anlaşmasının icrasının talep edildiği yer olduğundan, icranın talep edildiği yer yakın bağlantılı hukuku işaret edebilecektir.

Bu noktada Türkiyede bulunan taşınmazlarla ilgili sulh anlaşmalarının icrasını ayrıca değerlendirmek gerekmektedir. Taşınmazlara ilişkin sözleşmeler ister aynına, ister kullanımına ilişkin olsun taşınmazın bulunduğu yer hukukuna tâbidir (MÖHUK m. 25). Dolayısıyla sulh anlaşmasının icrası talebi, bir başka ifadeyle tapuda tescilin yapılması istemi sulh anlaşmasının Türk hukukuna göre geçerli olmasına bağlıdır. Yabancı adına tescil talebinde de sulh anlaşmasının yabancılar hukukunda getirilen kısıtlamalara uygun olması zorunludur. Dolayısıyla taşınmaza ilişkin bir sözleşmeden kaynaklanan uyuşmazlığın arabuluculuk yoluyla çözümlenmesi halinde varılan sulh anlaşması, taşınmazın bulunduğu yer hukukuna göre hükümsüz, tesirsiz veya uygulanması imkânsız ise icrası da reddedilebilecektir.

50 SCHNABEL, s. 43.

51 Id. s. 45.

52 Karakteristik edim teorisi konusunda ayrıntılı bilgi için bkz. ŞANLI, Cemal/ESEN, Emre/ATAMAN-FİGANMEŞE, İnci: Milletlerarası Özel Hukuk, 7. Bası, İstanbul 2019, s. 293 vd; NOMER, Ergin: Devletler Hususi Hukuku, 22. Bas1, İstanbul 2017, s. 331 vd; TEKİNALP, Gülören/UYANIK, Ayfer: Milletlerarası Özel Hukuk Bağlama Kuralları, 12. Bas1, İstanbul 2016, s. 287 vd. 
Taşınmazların mülkiyet nakline ilişkin sulh anlaşmaları taşınmazın bulunduğu ülke mahkemelerinden talep edilecektir. Buna göre Türkiyede bulunan bir taşınmaz ile ilgili olarak tapuda tescil işleminin gerçekleşmesi için Türkiye'de dava açılması halinde, sulh anlaşması Türk hukukunun emredici hükümlerine ve özellikle yabancıların taşınmaz iktisabındaki kısıtlamalara aykırılık teşkil ediyorsa söz konusu sulh anlaşmasının icrası reddedilecektir.

MÖHUK m. 25 taşınmazlar üzerindeki hem ayni haklar (ör: satım sözleşmesi) hem kullanım hakkına (ör: kira sözleşmesi) ilişkin sözleşmelerde hukuk seçimine izin vermemiştir. Dolayısıyla taşınmazlara ilişkin bir sulh anlaşmasının da tarafların seçtiği hukuka tâbi tutulması mümkün değildir. Türkiyede bulunan taşınmazlara ilişkin uyuşmazlıkların arabuluculuğa elverişli olduğu kabul edildiğinde ${ }^{53}$ milletlerarası bir sulh anlaşmasının Türkiyede icrası yani tapuda tescil yapılması talebi, sulh anlaşmasının Türk maddi hukukuna göre geçerli olmasına bağlıdır. Yabancı adına tescil talebinde ise sulh anlaşması yabancılar hukukundaki kısıtlamalara uygun olmalıdır.

Burada red sebebi olarak zikredilen geçersizlik şartı maddi hukuka ilişkindir. Sulh anlaşmasının, temelini oluşturan arabuluculuk prosedürüne aykırı olması örneğin arabulucunun lisanslı olmaması hususu, arabulucuların kurumsal arabuluculuk usullerine aykırı davranması veya sulh anlaşmasının noter ya da mahkemeden şerh almamış olması icra talebinin reddine neden olmayacaktır ${ }^{54}$.

\section{c) Sulh anlaşmasının bağlayıcı olmaması veya nihai olmaması ya da sonradan değiştirilmesi}

Sulh anlaşmasının, anlaşma hükümlerine göre bağlayıcı olmaması veya nihai olmaması icra talebinin reddi sebebidir (m. 5(1)(b)(ii)). Bu hüküm tarafların ancak açıkça anlaşmanın bağlayıcı veya nihai olmadığını belirtmeleri halinde uygulama imkânı bulacaktır ${ }^{55}$.

Taraflar sulh anlaşması yaptıktan sonra anlaşmayı değiştirmişlerse önceki sulh anlaşmasının icrası istenemeyecektir (m. 5(1)(b)(iii). Değiştirilmiş sulh anlaşması önceki anlaşmanın yerine geçmiş olmaktadır ve icrası söz konusu olan anlaşma önceki değil, değiştirilmiş olan yeni anlaşmadır. Sulh anlaşmasının değiştirildiği durumda eski anlaşmanın icrasının talep edilmesi halinde davalı, icranın talep edildiği ülke mahkemesi veya yetkili makamına sulh anlaşmasının değiştirildiğini ileri sürerse, icra talebi reddedilecektir. Ancak bunun için değiştirilmiş sulh anlaşmasının yetkili mahkemeye sunulması gerekir ${ }^{56}$.

\section{d) Sulh anlaşmasının ifa edilmiş olması}

Sulh anlaşmasında belirlenen borç ifa edilmişse, sulh anlaşmasının icrası talep edilemeyecektir (m. 5(1)(c)(i)). Kısmi ifa halinde ise icra talebi ancak ifa edilmeyen kısım için yapılabilir.

\footnotetext{
53 Bkz. IV i)

54 SCHNABEL, s. 44.

55 Id. s. 45.

56 Id. s. 47.
} 


\section{e) Sulh anlaşmasının açık veya anlaşılabilir olmaması}

Sulh anlaşmasının açık, anlaşılabilir olmaması icranın reddi sebebi olarak düzenlenmiştir (m. 5(1)(c)(ii). Kötü kaleme alınmış, hükümleri karışık ve anlaşılamaz sulh anlaşmalarının icrası kabul edilmemiştir ${ }^{57}$.

\section{f) İcranın sulh anlaşmasının hükümlerine aykırı olması}

Madde 5(1)(d)'ye göre icra talebi sulh anlaşmasının hükümlerine aykırı ise talep reddedilebilecektir. Buna göre taraflar sulh anlaşmasının icrası için yetki anlaşması yapmışlar yani hangi ülkede anlaşmanın icrası için başvuru yapılacağını açıkça kararlaştırmışlarsa, buna aykırı talep kabul edilmeyecektir. Aynı şekilde sulh anlaşmasının tarafları Singapur Konvansiyonu’nun uygulanmaması yönünde anlaşmışlarsa, icra talebine Konvansiyon hükümleri uygulanmayacaktır ${ }^{58}$.

\section{g) Arabulucunun görevi kötüye kullanması}

Konvansiyon arabulucudan kaynaklanan sebeplerle sulh anlaşmasının icrasının reddini de kabul etmiştir. Buna göre arabulucu, arabulucuya ve arabuluculuğa uygulanan standartları ciddi şekilde ihlal etmişse ve bu ihlal olmasaydı ilgili taraf sulh anlaşmasını yapmayacak idiyse, anlaşmanın icrası reddedilebilecektir (m. 5(1)(e)). Bu hükme göre icra talebinin reddedilebilmesi için ilgili tarafın bu hususları göstermesi gerekmektedir. Arabulucuların tâbi olduğu standartlar-örneğin tarafsızlık, bağımsızlık, taraflara eşit muamele yapılması gibi - Model Kanunda ya da ülkelerin kendi arabuluculuk düzenlemelerinde yer almaktadır. Burada standartların herhangi bir ihlali değil, sulh anlaşmasının yapılmasına neden olacak şekilde ciddi bir ihlal aranmıştır. Bu bağlamda sebep-sonuç illiyet bağının gösterilmesi önemlidir ${ }^{59}$.

Aynı durum arabulucunun taraflara, bağımsızlığı ve tarafsızlı̆̆ı konusunda haklı olarak şüphe uyandıracak durumları açıklamaması halinde de geçerlidir. Arabulucunun taraflara açıklamadığı hususun önemli ve sonuca etkili olduğu durumlarda, o husus açıklansaydı ilgili tarafın o sulh anlaşmasını yapmayacağı hallerde, varılan sulh anlaşmasının icrası reddedilecektir (m. 5(1)(f)). Burada arabulucunun tarafsızlığı veya bağımsızlığına haklı olarak şüphe uyandıracak durumun ciddi ve önemli bir durum olması vurgulanmıştır; taraflarca geçmişte mevcut olan bir ilişkinin açıklanmamış olması yeterli değildir. Diğer yandan ilgili durum zaten taraflarca biliniyorsa, sulh anlaşmasının icrası talebi bu nedenle reddedilmeyecektir ${ }^{60}$. Zira arabulucunun taraflar üzerinde zorlayıcı etkisinin olmaması ve anlaşmanın tarafların serbest iradeleriyle yapılması, arabulucu kaynaklı nedenlerle icranın reddini çok sınırlı bir alana itmektedir.

57 Ayrıntılı bilgi için bkz. SCHNABEL, s. 48.

58 SCHNABEL, s. 48-49.

59 SCHNABEL, s. 50-51; SILVESTRI, s. 196; CHUA, s. 7-8.

60 SCHNABEL, s. 53. 


\section{h) Sulh anlaşmasının icrasının kamu düzenine aykırılığı}

Konvansiyon m. 5(2)(a) ile sulh anlaşmasının icrasının taraf devletin kamu düzenine aykırı olmasını bir red sebebi olarak düzenlemiştir. New York Konvansiyonu’nda da yer alan kamu düzeni kavramının istisnai ve dar yorumlanmasına ilişkin yaklaşımın sulh anlaşmasının icrasında da geçerli olduğu kabul edilmektedir. Buna göre taraf devletler, ancak lisanslı arabulucuların faaliyet göstermesini kamu düzeninden sayıp bu gerekçeyle sulh anlaşmasının icrasını reddedemeyecektir. Çalışma Grubu ulusal güvenlik meselelerini kamu düzeni istisnası çerçevesinde değerlendirmiştir ${ }^{61}$. Ahlâka aykırı bir borcun ifasını mümkün kılan (örneğin rüşvet vererek bir işlemin yapılmasını sağlayan aracının hak ettiğini iddia ettiği komisyonla ilgili) sulh anlaşmalarının icrası kamu düzenine aykırı kabul edilecektir.

Diğer yandan mahkeme ilâmları/hakem kararlarının tenfizinde uygulanan kamu düzeni kapsamında ele alınan adil yargılanma hakkının ihlali, yargılama usulüne aykırılık gibi hususlar arabuluculuk bir yargılama faaliyeti olmadığı, gizlilik içinde gerçekleştiği ve çözümü taraflar belirlediği için, sulh anlaşmasının icrasında etkin olmayacaktır ${ }^{62}$. Dolayısıyla sulh anlaşmasının icrasında kamu düzeninin oynayacağı rolün, hakem kararlarının tenfizindeki etkisine kıyasla çok daha düşük olacağı savunulmaktadır ${ }^{63}$.

\section{i) Uyuşmazlık konusunun arabuluculuğa elverişli olmaması}

Uyuşmazlık konusu taraf devletin hukukuna göre arabuluculukla çözümlenmeye elverişli değilse sulh anlaşmasının icrası reddedilebilecektir (m. 5(2)(b)). Burada tahkime elverişsizlik gibi arabuluculuğa elverişsizlik de bir icra engeli olarak düzenlenmiştir.

Konvansiyon sulh anlaşmasının icrasını değil, temeldeki uyuşmazlığın arabuluculuğa elverişli olmasını aramıştır. Dolayısıyla icranın talep edildiği ülkede zorunlu olarak devlet yargısında görülmesi gereken meseleler arabuluculuğa elverişli olmadığı için, bu meselelerin çözümü için yapılan sulh anlaşmaları söz konusu ülkede icra edilemeyecektir ${ }^{64}$.

Türk HUAK m. 1'e göre arabuluculuk ancak tarafların üzerinde serbestçe tasarruf edebilecekleri iş ve işlemlerden doğan özel hukuk uyuşmazlıklarının çözümünde uygulanır. Aile içi şiddet iddiasını içeren uyuşmazlıklar arabuluculuğa elverişli değildir. Singapur Konvansiyonu aile, iş, miras ve tüketici hukukuna ilişkin uyuşmazlıkları kapsam dışında bıraktığı için ticari uyuşmazlıklar içinde tahkime elverişli olmayan yani sadece devlet mahkemesinde çözümlenmesi gereken meseleler arabuluculuğa da elverişli değildir. Buna göre rekabet hukukundan kaynaklanan uyuşmazlıklarda Rekabetin Korunması Hakkında Kanun ${ }^{65}$ uyarınca oluşturulan Rekabet Kurulu, kanunun

61 Id. s. 54.

62 CHUA, s. 7.

63 ZELLER/TRAKMAN, s. 461.

64 SCHNABEL, s. 54-55.

65 RG. 13.12.1994-22140. 
uygulanmasından doğan uyuşmazlıklarda görevli ve yetkili kılınmıştır (m. 27). Dolayısıyla Kurulun yetkisi dahilindeki konularda tahkime gitmek mümkün olmadığ ${ }_{1}^{66}$ gibi arabuluculuk da söz konusu olmayacaktır.

Aynı şekilde iflas davaları, fikri hakların varlığı veya yokluğuna ilişkin uyuşmazlıklar tahkime elverişli olmadığ ${ }^{67}$ gibi arabuluculuk yoluyla da çözümlenemez.

Şirketler hukuku alanında ${ }^{68}$ tahkime elverişlilik açısından tartışmalı olan anonim şirket genel kurul kararının iptali ve şirketin feshine ilişkin uyuşmazlıkların ${ }^{69}$ arabuluculuğa da elverişli olmadığ 1 söylenebilir. Şirket genel kurulunun iptali ile ilgili uyuşmazlıklarda davacı TTK m. 446'da sayılanlar, davalı ise yönetim kuruludur. Yönetim kurulunun yetkileri arasında genel kurul kararlarının iptali sayılmadığı için genel kurul kararının iptali için bir sulh anlaşması yapması yetkisini aşması anlamına gelmekte dolayısıyla yönetim kurulunun, iptal davasının konusu üzerinde tasarruf yetkisinin bulunmadığ sonucuna varılmaktadır. Bu itibarla genel kurul kararlarının iptali arabuluculuğa elverişli değildir ${ }^{70}$.

Tahkime elverişliliği düzenleyen HMK m. 408 ve MTK m. 1 iki tarafın iradelerine tâbi olmayan işlerden kaynaklanan uyuşmazlıkların tahkime elverişli olmadığını belirtmekle yetinmemiş, Türkiye'de bulunan taşınmazlar üzerindeki ayni haklardan kaynaklanan uyuşmazlıkların tahkime elverişli olmadığını ayrıca ve açıkça vurgulamıştır. Buna karşılık HUAK m. 1'de taşınmazlar zikredilmemiş sadece tarafların üzerinde serbestçe tasarruf edebilecekleri uyuşmazlıklar için arabuluculuğa imkân tanınmıştır. Bu itibarla Türkiyede bulunan taşınmazların aynına ilişkin uyuşmazlıkların arabuluculuk yoluyla çözümlenip çözümlenmeyeceğinin irdelenmesi gerekmektedir.

$\mathrm{Bu}$ bağlamda belirlenmesi gereken husus taşınmazların aynına ilişkin uyuşmazlıkların, tarafların serbestçe tasarruf edebilecekleri uyuşmazlıklar arasında yer alıp almadığı meselesidir. Taşınmazların aynına ilişkin uyuşmazlıklar malikin tasarruf yetkisine getirilen kamu hukuku kısıtlamaları (TMK m. 754 vd) ile ilgili ise, bu uyuşmazlıklar niteliği gereği arabuluculuğa elverişli değildir $^{71}$. Buna karşılık özel hukuka ilişkin kısıtlamalar örneğin taşınmaz mülkiyeti üzerinde malikin tasarruf yetkisini kısıtlayan şerh edilmiş alım, ön-alım veya geri-alım hakları ile ilgili

Bkz. ÖZEL, Sibel: Milletlerarası Ticari Tahkimde Kanunlar İhtilafı Meseleleri, İstanbul 2008, s. 42-43.

ÖZEL, s. 44 vd. Ayrıca bkz. HUYSAL, Burak: Milletlerarası Ticari Tahkimde Tahkime Elverişlilik, İstanbul 2010, s. $282 \mathrm{vd}$

Şirketler hukukundan kaynaklanan uyuşmazlıklarda arabuluculuk konusunda ayrıntılı bilgi için bkz. BÜYÜKAY, Ferhat: Arabuluculuk Anlaşma Belgesi ve İcra Edilebilirlik Şerhi, Ankara 2018, s. 211 vd.

Bkz. AKINCI, Ziya/YASAN-TEPETAŞ, Candan (editörler) : Şirketler Hukuku Uyuşmazlıkları ve Tahkim, İstanbul 2018, s. 92, 93, 95, 96, 150, 172, 173, 174. Ayrıca bkz. HUYSAL, s. 308 vd; HELVACI, Mehmet: "Anonim Ortaklık Genel Kurul Kararlarının İptali Davalarının Tahkim Yargılamasına Uygunluğu Üzerine Düşünceler” II. Uluslararası Özel Hukuk Sempozyumu “TAHKİ”” 14 Şubat 2009, Konuşmalar-Tartışmalar-Bildiriler (editörler: Erol ULUSOY/ Aslı YILDIRIM), TMSF, 2009, s. 179 vd.

70 BÜYÜKAY, s. 217-218. Limited şirketlerde ortaklar kurulu kararının iptaline de anonim şirketlere ilişkin hükümler uygulanacağı için limited şirketlerde ortaklar kurulu kararının iptali de arabuluculuğa elverişli değildir. Id. s. 218. Aynı yönde bkz. KOÇYİĞİT/PULUR, s. 75.

BÜYÜKAY, s. 199. 
uyuşmazlıklar arabuluculuğa elverişli olacaktır ${ }^{72}$. Dolayısıyla HUAK'da açıkça taşınmazların aynına ilişkin uyuşmazlıkların arabuluculuğa elverişli olmadığı belirtilmediği ve taşınmazın aynına ilişkin uyuşmazlıklar tarafların serbestçe tasarruf edebileceği konular arasında yer aldığı için arabuluculuğa elverişli kabul edilmektedir ${ }^{73}$.

Dolayısıyla taşınmazın aynına ilişkin konularda yapılacak işlemlerin (hem borçlandırıcı işlem hem de ayni işlem) resmi şekilde yapılma zorunluluğu (TMK m. 706) arabuluculuğa başvuruyu engellemeyecektir ${ }^{74}$. Ancak sulh anlaşmasının tapuda tescil ile icrası yapılamayacaktır. Taşınmazın aynına ilişkin uyuşmazlığı sonlandıran sulh anlaşması için mahkemeden icra edilebilirlik şerhi de talep edilemeyeceği gibi, HUAK m. 18(4) şartlarını taşıyan belge de ilam niteliğinde belge değildir. Zira hukukumuzda taşınmazın aynına ilişkin hususların cebri icra ile yerine getirilmesi düzenlenmemiştir ${ }^{75}$. Bu noktada arabuluculuğa elverişlilik kavramı ile arabuluculuk sonucunda yapılan sulh anlaşmasının icraya elverişliliği kavramlarının arasındaki farka dikkat çekilmelidir. HUAK’a göre yapılan sulh anlaşması İcra İflas Kanunu ${ }^{76}$ m. 38 anlamında ilam niteliğinde belgedir ve dolayısıyla ilamlı icra talebine konu olabilir. Ancak sulh anlaşmasının ilamlı icra talebine konu olabilmesi için içerik yönünden cebri icraya elverişli olması yani konusunun belli bir edimin ifasına (bir miktar paranın verilmesi, malın teslimi, bir fiilin yapılması veya yapılmaması gibi) yönelik olması gerekir ${ }^{77}$. Taşınmaz üzerindeki ayni hakkın devrini öngören bir sulh anlaşması bu bağlamda ilam niteliğinde belge değildir ve Türk hukuku açısından icraya elverişsizdir. Bu nedenle taraflar taşınmazın aynına ilişkin uyuşmazlıklarını arabuluculuk yoluyla çözümleyebilirler; ancak neticede varılan sulh anlaşması borçlu tarafından yerine getirilmezse, ilgilinin bu anlaşmaya dayanarak tapuda kendi adına tescil yaptırması mümkün değildir. Varılan sulh anlaşmasının icrası ancak mahkemeden istenebilecektir. Sulh anlaşmasına göre adına tescil istemek konusunda kişisel hakka sahip olan kişi, hâkimden mülkiyetin hükmen geçirilmesini isteyebilir (TMK m. 716).

Türk hukukunda taşınmazlara ilişkin işlemlerin tapuda resmi şekilde yapılması zorunluluğu icraya ilişkin bir mesele olup, arabuluculuğa elverişliliği engellememektedir. Bu bağlamda Türkiye’deki taşınmazların aynına ilişkin düzenlemeyi öngören bir sulh anlaşmasının Singapur Konvansiyonu kapsamında icrası talebi sırf bu nedenle reddedilmeyecektir. Zira Konvansiyon sulh anlaşmasının icraya elverişsizliğini değil, temeldeki uyuşmazlığın arabuluculuğa elverişsizliğini bir red sebebi olarak düzenlemiştir. Bu nedenle taşınmaza ilişkin uyuşmazlıklar arabuluculuğa elverişli olduğu için bununla ilgili sulh anlaşmalarının icrası da Singapur Konvansiyonu kapsamında talep edilebilecektir. Ancak Türk mahkemesi böyle bir durumda yukarıda açıkladığımız üzere sulh anlaşmasının Türk hukukuna uygun olup olmadığını inceleyecektir. Sulh anlaşması, Konvansiyon

72 Id. 199. TMK'da kanun hükmüyle getirilen diğer kıstllamalarla ilgili bkz. Id. s. 200.

73 BÜYÜKAY, s. 200; KOÇYİĞIT/PULUR, s. 75. Ayrıca bkz. TAŞPOLAT-TUĞSAVUL, Melis: Türk Hukukunda Arabuluculuk, Ankara 2012, s. 118 vd; ERDOĞAN/CÖMERT, s. 38.

74 BÜYÜKAY, s. 201.

75 Id. s. 201.

76 RG. 19.06.1932-2128.

77 TAŞPOLAT-TUĞSAVUL (Hukuki nitelik) s. 356. 
m. 5(1)(b)(i) anlamında Türk hukukuna göre hükümsüz, tesirsiz veya uygulanması imkânsız ise ve ayrıca m. 5(2)(a) uyarınca kamu düzenine aykırı ise icra talebi yani ilgili adına tapuda tescil istemi reddedilecektir.

Yabancıların Türkiye'deki taşınmazlar üzerindeki ayni hak kazanımının da ayrıca incelenmesi gerekmektedir. Arabuluculuk hangi hukuka göre gerçekleşirse gerçekleşsin (HUAK veya yabancı bir arabuluculuk kanunu) yapılan sulh anlaşmasında yabancının Türkiyedeki bir taşınmaz üzerinde ayni hak iktisabı kararlaştırılmış ise, bu anlaşmanın geçerliliği Türk hukukuna tâbidir. Bu kapsamda yabancilar hukuku ile ilgili kısitlamalar ve yasaklamalar devreye girecektir. Tapu $\mathrm{Kanunu}^{78}$ m. 35/I yabancı gerçek kişiler için kısıtlamalara tâbi olarak taşınmaz ve sınırlı ayni hak edinimine izin vermiştir. Tapu K. m. 35/II ise yabancı ülkelerde kurulan tüzel kişiliğe sahip ticaret şirketlerinin ancak özel kanun izin veriyorsa taşınmaz ve sınırlı ayni hak edinebileceğini öngörmüş; yabancı vakıf ve derneklerin ve diğer tüzel kişilerin Türkiye’de taşınmaz edinimini yasaklamıştır. Diğer yandan Tapu K. m. 36 yabancıların Türkiye'de kurdukları şirketlerin taşınmaz edinimine ilişkin kısıtlamalar getirmiş; Vakıflar Kanunu ${ }^{79}$ m. 12/son kurucularının yabancı olduğu Türkiye’de kurulmuş vakıfların taşınmaz edinimini Tapu K. m. 35’e tâbi tutarak yasaklamıştır. Ayrıca Askeri Yasak Bölgeler ve Güvenlik Bölgeleri Kanunu ${ }^{80}$ da konuya ilişkin hükümler getirmiştir. Dolayısıyla kamu hukuku açısından yasaklamalar ve kısıtlamalar bulunmaktadır. Bu sınırlamalar dahilinde arabuluculuk yoluyla sulh anlaşması yapılabilir ${ }^{81}$. Ancak sulh anlaşması Türk hukukundaki sınırlamalara ve yasaklara aykırı ise bu anlaşmanın icrası yani mahkeme hükmüyle adına tapuda tescil mümkün olmayacaktır.

Sonuç itibariyle arabuluculuk sonucu yapılan sulh anlaşması Türkiye'deki bir taşınmazın aynına ilişkin bir düzenleme getiriyorsa, bu anlaşmanın Singapur Konvansiyonu kapsamında icrası ancak sulh anlaşmasının Türk hukukuna uygun olması ve kamu düzenine aykırı olmaması halinde mümkündür.

\section{V. ÇEKINCELER}

Singapur Konvansiyonu iki hususta ${ }^{82}$ taraf devletlere çekince koyma hakkı tanımıştır:

a) Taraf devlet kendisinin veya hükümet kuruluşlarının veya hükümet kuruluşları adına hareket eden bir kişinin taraf olduğu sulh anlaşmalarının icrasına bu Konvansiyonu uygulamayacağını deklere edebilir (m. 8(1)(a)). Çalışma Grubu böylelikle taraf devletlere esneklik tanımıştır. $\mathrm{Bu}$ çekince ile taraf devlet ulusal hukuka göre yetkilendirilmemiş bir kişinin ya da kuruluşun yaptığı sulh anlaşmasının yol açabileceği problemlerden kaçınmış olacaktır ${ }^{83}$.

RG. 29.12.1934-2892.

RG. 27.02.2008-26800.

RG. 22.12.1981-17552.

Tapu K. m. 35'deki sınırlamalara uygun olarak arabuluculuk yapılabileceği konusunda bkz. BÜYÜKAY, s. 203.

Bu iki husus dışında çekinceye izin verilmemiştir. m. 8(2).

SCHNABEL, s. 56. 
b) Taraf devlet sulh anlaşmasında tarafların Konvansiyonun uygulanmasını öngörmeleri halinde Konvansiyonu uygulayacağını deklare edebilir (m. 8(1)(b)). Çalışma Grubunda Konvansiyonun taraflarca seçilmesi halinde uygulanması önerisi yapılmış ancak bu öneri, tarafların sulh anlaşması yapması halinde karine olarak bunun sınır-ötesi icrasını da öngördüklerini ayrıca icrayı mümkün kılmak için böyle bir açılama yapmak zorunda olmadıkları gerekçesiyle reddedilmiştir. Dolayısıyla taraflar Konvansiyonun uygulanması konusunda hiçbir açıklama yapmadığında, onların borçlarını ifa etmek istemediklerine ilişkin hiçbir varsayım kabul edilmeyecektir ${ }^{84}$.

Bu itibarla tarafların Singapur Konvansiyonu’nun uygulanmamasını açıkça kararlaştırdıkları sulh anlaşmaları hariç, Konvansiyon kapsamı dahilindeki bütün sulh anlaşmalarına uygulanacaktır. Ancak m. 8(1)(b)'deki deklarasyonu yapan devlet, sadece tarafların Singapur Konvansiyonunun uygulanmasını kararlaştırdıkları sulh anlaşmaları için Konvansiyonu uygulayacaktır. Tarafların bu seçimi sulh anlaşmasından önce, arabuluculuk anlaşmasında da yapmaları mümkündürr ${ }^{85}$.

Söz konusu çekince bir uzlaşmanın sonucu getirildiği için Singapur Konvansiyonunun hedefini gerçekleştirmesi açısından mümkün olduğunca az devletin bu çekinceyi kabul etmesi temenni edilmektedir ${ }^{86}$.

\section{SONUÇ}

20 Aralık 2018 tarihli Arabuluculuk Sonucunda Yapılan Milletlerarası Sulh Anlaşmaları Hakkında Birleşmiş Milletler Singapur Konvansiyonu 7 Ağustos 2019 tarihinde imzaya açılmış ve ilk gün 46 ülke tarafından imzalanmıştır ${ }^{87}$. Türkiye’nin ilk imzacılar arasında yer aldığ Konvansiyonu Çin ve ABD’nin imzalaması önemlidir. Ancak henüz hiçbir AB üyesi ülke ve İngiltere imzalamamıştır. Konvansiyon, m. 14’e göre üç ülkenin onay, kabul, tasdik veya katılımından 6 ay sonra yürürlüğe girecektir.

Singapur Konvansiyonu sulh anlaşmalarının basit ve hızlı bir şekilde sınır-ötesi icrasını mümkün kılarak milletlerarası ticarette arabuluculuk yönteminin daha sık kullanımını sağlamayı da hedeflemektedir. Bu durum her şeyden önce çok sayıda devletin Konvansiyona taraf olması ve bunu iç hukukuna dahil etmesi ile mümkündür.

Singapur Konvansiyonu’nu imzalayan Türkiye’nin de Konvansiyon hükümlerini ayrı bir uyum kanunu ile iç hukukuna dahil etmesi ve bu kanunla milletlerarası sulh anlaşmalarının icrası için yetkili/görevli mahkemeyi göstermesi gerekmektedir ${ }^{88}$. Sulh anlaşmalarının geçersizliği,

84 Id. s. 56-57.

85 Id. s. $57-58$.

86 SCHNABEL, s. 58; CHUA, s. 9.

87 İmzacı ülkeler listesi için bkz. http://hsfnotes.com (6.10.2019)

88 Yabancı Hakem Kararlarının Tanınması ve Tenfizine ilişkin New York Konvansiyonu bir uyum kanunu ile iç hukuka geçirilmemiş ve Sözleşme olarak MÖHUK m. 1(2) uyarınca mahkemelerde uygulanmaktadır. Ancak yabancı hakem kararlarıyla ilgili MÖHUK hükümlerinin usulî meseleleri çözümlemesi ve New York Konvansiyonu 
arabuluculara ilişkin standartların ihlali, kamu düzeni ve arabuluculuğa elverişsizlik gibi red sebeplerinin değerlendirilmesi mahkeme dışı bir makama bırakılamaz.

Singapur Konvansiyonu yanında milletlerarası ticari arabuluculuk ve sulh anlaşmalarına uygulanmak üzere Model Kanunu baz alan bir iç hukuk düzenlemesinin yapılması da yerinde olur. Zira şu an yürürlükte olan HUAK yabancılık unsuru taşıyan ancak kanun kapsamında ve Türk vatandaşı arabulucular tarafından gerçekleştirilen prosedür sonucu yapılan sulh anlaşmalarını ilam niteliğinde belge olarak nitelendirerek Türkiyede icrasını mümkün kılmıştır. Bu bağlamda HUAK dışı bir kanun çerçevesinde yürütülen arabuluculuk sonucu yapılan sulh anlaşmalarının icrası Singapur Konvansiyonu’na göre talep edilecektir.

Ancak arabuluculuğa elverişlilik ile sulh anlaşmalarının icraya elverişliliğinin farklılığına dikkat çekilmelidir. Türkiye'de bulunan taşınmazlarla ilgili sulh anlaşmalarının icrası ancak Türk mahkemelerinden alınan bir ilâmla mümkün olmaktadır. Dolayısıyla taşınmazlarla ilgili uyuşmazlıkları arabuluculuğa elverişli gören HUAK, bu arabuluculuk sonucu yapılan sulh anlaşmalarının doğrudan icrasına izin vermemiştir. Türkiye'de bulunan taşınmazlara ilişkin sulh anlaşmalarının icrası Singapur Konvansiyonu’na göre talep edildiğinde icranın yani tescil talebinin sulh anlaşmasıyla yapılamayacak olması değil, temeldeki uyuşmazlığın arabuluculuğa elverişsiz olması bir red sebebidir. Bu yüzden Türkiye’deki taşınmazların aynına ilişkin uyuşmazlıkların arabuluculukla çözümlenmesinin mümkün olmadığı açıkça belirtilmedikçe, arabuluculuğa elverişli olan bu konuda yapılan sulh anlaşmasının icrası da Konvansiyon kapsamına girmiş olacaktır. Zira Konvansiyon parasal olmayan sulh anlaşmalarının icrasını da mümkün kılmaktadır. Bu durumda milletlerarası sulh anlaşmasına binaen Türk mahkemesinden Türkiye'deki taşınmazın tesciline karar vermesi istenebilir. Türk emredici kurallarına aykırı ve yabancılarla ilgili kısıtlamaların dikkate alınmadığı bir sulh anlaşmasının reddi ancak bu anlaşmanın m. 5(b)(i)'ye göre Türk hukukuna göre geçersiz olduğu veya m. 5(2)(a)'ya göre Türk kamu düzenine aykırı olduğu gerekçesiyle reddedilebilir.

\section{KAYNAKÇA}

ABOU EL FARAQ, Muhammed Salem: “The Enforcement of Settlement Agreements Resulting From Mediation - A Qatari Perspective” 19 Asian Bus. Law. 49 (2017).

AKINCI, Ziya/YASAN-TEPETAŞ, Candan (editörler) : Şirketler Hukuku Uyuşmazlıkları ve Tahkim, İstanbul 2018.

BOULLE, Laurence/QIN, Jay: “Globalising Mediated Settlement Agreements” 3 J.Int'1\&Com.L. 33 (2016).

BÜYÜKAY, Ferhat: Arabuluculuk Anlaşma Belgesi ve İcra Edilebilirlik Şerhi, Ankara 2018.

CHUA, Eunice: “The Singapore Convention on Mediation - A Brighter Future for Asian Dispute Resolution” Asian Journal of International Law, 1 (2018).

ile paralel hükümler getirmesi bu noktada önemlidir. Buna karşılık arabuluculuk sonucu yapılan milletlerarası sulh anlaşmalarının icrasına yönelik yani hangi durumlarda icranın reddedilebileceğine ilişkin bir iç hukuk mevzuatı bulunmamaktadır. O yüzden Singapur Konvansiyonu’nun bir uyum kanunu ile iç hukuka dahil edilmesi gerekmektedir. 
ÇELİKOĞLU, Cengiz Topel: “6325 Sayılı HUAK’a Göre Arabuluculuk Yoluna Başvurulması ve Çözüm Anlaşmasının Mahkeme ve İcra Usulleri ile İlişkisi” Yılmaz Ejder’e Armağan, Ankara 2014, c.1, s. 669.

ELÇIN, Doğa: Milletlerarası Ticari Tahkim Hukukunda Sulh, Ankara 2019.

ERDOĞAN, Ersin/CÖMERT, Büşra: "Arabuluculuk Sonunda Hazırlanan Anlaşma Belgesinin Hukuki Niteliği ve Anlaşma Belgesine Karşı Başvurulabilecek Hukuki Çareler” Terazi Hukuk Dergisi, c. 13, S. 138 , s. 27.

HELVACI, Mehmet: “Anonim Ortaklık Genel Kurul Kararlarının İptali Davalarının Tahkim Yargılamasına Uygunluğu Üzerine Düşünceler” II. Uluslararası Özel Hukuk Sempozyumu “TAHKİM” 14 Şubat 2009, Konuşmalar-Tartışmalar-Bildiriler (editörler: Erol ULUSOY/Aslı YILDIRIM), TMSF, 2009, s. 179.

HUYSAL, Burak: Milletlerarası Ticari Tahkimde Tahkime Elverişlilik, İstanbul 2010.

KOÇYİĞİT, İlker/PULUR, Alper: Ticari Uyuşmazlıklarda Dava Şartı Arabuluculuk, Hukuk İşleri Genel Müdürlüğü Arabuluculuk Daire Başkanlığı Yayını, Mart 2019, (http://www.adb.adalet.gov.tr ).

NOMER, Ergin: Devletler Hususi Hukuku, 22. Bası, İstanbul 2017.

ÖZEL, Sibel: Milletlerarası Ticari Tahkimde Kanunlar İhtilafı Meseleleri, İstanbul 2008.

ÖZSUNAY, Ergun: “Arabuluculuk Sonucunda Yapılan Uluslararası Sulh Anlaşmaları Hakkında Birleşmiş Milletler Sözleşmesi: Singapur Arabuluculuk Sözleşmesi Türk Hukukuyla Uyumu Bakımından Bir Değerlendirme” İstanbul Barosu Dergisi, Mayıs-Haziran 2019, c. 93, S. 3, s. 31.

PÜRSELIM, Hatice Selin: "Yabancılık İçeren Arabuluculuk Usulü ve Bağlayıcılık Hakkında Düşünceler" Marmara Üniversitesi Hukuk Fakültesi Hukuk Araştırmaları Dergisi, c. 20, S.2, 2014, s. 3-21.

REED, Lucy: "Ultima Thule: Propects for International Commercial Mediation" (NUS Centre for International Law Working Paper 19/03-January 2019) (http://cil.nus.edu.sg/library/ ).

SCHNABEL, Timothy: "The Singapore Convention on Mediation: A Framework for the Cross-border Recognition and Enforcement of Mediated Settlement" 19 Pepperdine Dispute Resolution Law Journal 1 (2019).

SILVESTRI, Elisabetta: “The Singapore Convention on Mediated Settlement Agreements: A New String to the Bow of International Mediation" Revista Electronica de Direito Processual, Rio de Janeiora Ano 13, v. 20, No. 2 Maio a Agosto de 2019, s. 189.

STRONG, S.I: "Beyond International Commercial Arbitration - The Promise of International Commercial Arbitration" 45 Wash. U.J.L\&Pol'y 10 (2014).

SUSSMAN, Edna: “The Singapore Convention the Enforcement and Recognition of International Mediated Settlement Agreements" 3 ICC Dispute Resolution Bulletin, 42 (2018).

ŞANLI, Cemal/ESEN, Emre/ATAMAN-FİGANMEŞE, İnci: Milletlerarası Özel Hukuk, 7. Bası, İstanbul 2019.

TAŞPOLAT-TUĞSAVUL, Melis: Türk Hukukunda Arabuluculuk, Ankara 2012.

TAŞPOLAT-TUĞSAVUL, Melis: "Arabuluculuk Faaliyeti Sonunda Varılan Anlaşmanın Hukuki Niteliği”" Galatasaray Üniversitesi Hukuk Fakültesi Dergisi, 2019/1, s. 333 (Hukuki nitelik)

TEKINALP, Gülören/UYANIK, Ayfer: Milletlerarası Özel Hukuk Bağlama Kuralları, 12. Bası, İstanbul 2016. YARAR, Güven: Milletlerarası Özel Hukukta Arabuluculuk, İstanbul 2019.

ZELLER, Bruno/TRAKMAN, Leon: "Mediation and Arbitration: The Process of Enforcement" 24 Uniform Law Review 449 (2019) (http://doi.org/10.1093/ulr/unz020). 